\title{
INSECTICIDAL ACTIVITY OF Toona sinensis AGAINST Coptotermes curvignathus Holmgren
}

\author{
Morina Adfa ${ }^{1,}$, Arif J. Kusnanda ${ }^{1}$, Fio Livandri', Rizki Rahmad ${ }^{1}$, \\ Welly Darwis $^{2}$, Mai Efdi ${ }^{3}$, Masayuki Ninomiya ${ }^{4,5}$, and Mamoru Koketsu ${ }^{4,5}$ \\ ${ }^{1}$ Department of Chemistry, Faculty of Mathematic and Natural Sciences, University of \\ Bengkulu, Jalan W.R. Supratman, Bengkulu 38371, Indonesia \\ ${ }^{2}$ Department of Biology, Faculty of Mathematic and Natural Sciences, University of Bengkulu, \\ Jalan W.R. Supratman, Bengkulu 38371, Indonesia \\ ${ }^{3}$ Department of Chemistry, Faculty of Mathematic and Natural Sciences, Andalas University, \\ 25163 Limau Manis, Padang, Indonesia \\ ${ }^{4}$ Department of Chemistry and Biomolecular Sciences, Faculty of Engineering, Gifu University, \\ 1-1 Yanagido, Gifu 501-1193, Japan \\ ${ }^{5}$ Department of Materials Science and Technology, Faculty of Engineering, Gifu University, \\ 1-1 Yanagido, Gifu 501-1193, Japan \\ *E-mail: morinaadfa@unib.ac.id; morinaadfa@yahoo.com
}

\begin{abstract}
Toona sinensis timbers are generally used in the furniture and building material in Indonesia, due to their reputed durability. The aim of this study was to identify the potential compounds responsible for the antitermite activity of $T$. sinensis against Coptotermes curvignathus. The methanol extracts of stem wood and stem bark of T. sinensis showed termiticidal activity. Our phytochemical investigated have been isolated two flavonoid compounds (+)-catechin (1) and its dimer procyanidin B3 (2) and one steroid compound $\beta$-sitosterol-D- glucoside (3) by bioassay-guided from Toona sinensis stem bark and tested them to antitermite activity by the no-choice test. In addition, we investigated the antitermite activity of (-)-epicatechin, (-)-epicatechin gallate and (-)-epigallocatechin gallate together with the isolated compounds in laboratory scale at a dose of $0.8 \% \mathrm{w} / \mathrm{w}$. The results showed that $(+)$-catechin had the highest antifeedant and termiticidal activity after 21 days exposure to all other compounds tested, but no significant difference in mortality to its dimer procyanidin B3, diastereoisomer (-)-epicatechin and galloylated catechin (-)-epigallocatechin gallate on statistical analysis.

Keywords: Toona sinensis, termiticidal, antifeedant, (+)-catechin, (-)-epicatechin, (-)-epigallocatechin gallate, Coptotermes curvignathus.
\end{abstract}

(C) RASĀYAN. All rights reserved

\section{INTRODUCTION}

Toona is one of tropical and sub-tropical timber belonging to the Meliaceae family. Species of this genus native to Asia region and distributed from southern north Korea through most eastern, central, and southwestern parts China to Thailand, Myanmar, India, Malaysia, and Indonesia ${ }^{1}$. Toona extract is a source of extractive and essential oil which is responsible for the medicinal and insecticidal properties against the variety of insect. The toxic effect of the extract of Toona sureni on the adults of red flour beetle (Tribolium castaneum) was studied ${ }^{2}$. Toonacilin and 6-acetoxytoonacilin isolated compounds of Toona ciliata showed a strong antifeedant effect on the Mexican bean beetle ${ }^{3}$.

Toona sinensis (A. Juss.) Roem. is locally known as Suren merah in Sumatera, Indonesia. The bark, root, and leaf extracts of $T$. sinensis was used for medicinal purposes, e.g. to treat diarrhea and as an antibiotic. $T$. sinensis has been reported to have various effects on several human cancer cell lines, including antiproliferative activity and induced apoptosis in a cancer cell ${ }^{4,5} . T$. sinensis extracts were found to have repellent activity against Sitophilus zeamais ${ }^{6} . T$. sinensis hardwood timbers are generally used in the 
furniture and building material, due to their reputed durability. However, there has been little research into the relationship between its wood properties and various extractives/chemicals content.

To our knowledge there is no prior study describing the antitermite activities of $T$. sinensis. Thus, we first examined the antitermite activity of stem bark, and stem wood methanol extracts of $T$. sinensis. In this study, we isolated compounds from $T$. sinensis stem bark and investigated their antitermite activities against $C$. curvignathus. In addition, we compared the antitermite activity of (+)-catechin isolated compound with its diastereoisomer and galloylated catechin.

\section{EXPERIMENTAL}

\section{General Chemical Procedures}

Thin-layer chromatography (TLC) spots on plates pre-coated with silica gel $60 \mathrm{~F}_{254}$ were detected with a UV lamp (254 nm and $365 \mathrm{~nm}) .{ }^{1} \mathrm{H}(400 \mathrm{MHz})$ and ${ }^{13} \mathrm{C}(100 \mathrm{MHz}) \mathrm{NMR}$ spectra were recorded with a JEOL ECX 400 spectrometer. MS spectra were obtained using a JEOL JMS-700/GI spectrometer. Silica gel column chromatography (CC) was performed on Silica Gel 60 N (40-50 $\mu \mathrm{m}$, neutral) (KANTO Chemical Co., Inc.). (-)-Epicatechin gallate was purchased from TCI, (-)-epicatechin was purchased from WAKO, (-)-epigallocatechin gallate was purchased from LKT Laboratories, Inc., and (+)-catechin standard was purchased from Sigma-Aldrich.

\section{Plant Material}

The stem bark and stem wood of $T$. sinensis were collected from Kenagarian Sungai Jernih, Kecamatan Gunung Talang, Kabupaten Solok, West Sumatera, Indonesia. The plant material was identified by Herbarium of Andalas University (ANDA).

\section{Extraction and Isolation}

Powdered air-dried stem bark of $T$. sinensis (TSSB) (3800 g) was extracted at room temperature with methanol $(3 \times 14 \mathrm{~L})$. The mixture was subsequently filtered and concentrated in vacuo to yield TSSB MeOH extract (207.6 g). An amount $31.6 \mathrm{~g}$ this extract was suspended in $\mathrm{MeOH}: \mathrm{H}_{2} \mathrm{O}$ (1:1) and partitioned with EtOAc to yield TSSB EtOAc $(21.07 \mathrm{~g})$, and TSSB water $(8.84 \mathrm{~g})$ fractions. Powdered air-dried stem wood of $T$. sinensis $(\mathrm{TSS})(230 \mathrm{~g})$ was extracted at room temperature with methanol $(3 \times 1.5 \mathrm{~L})$. The mixture was subsequently filtered and concentrated in vacuo to yield TSS MeOH extract (27.15 g). This extract was suspended in water and partitioned with EtOAc to yield TSS EtOAc (25.20 g), and TSS water (1.89 g) fractions.

The EtOAc fraction of stem bark (21.07 g) was subjected to flash silica gel column using n-hexane/EtOAc (9/1 to 0/10) and EtOAc/MeOH (9/1 to 5/5) as the eluents to collected 11 fractions (E1-E11) which were combined according to TLC analysis. Fraction E7, E8 and E9 and their sub-fractions were subjected to CC, afforded (+)-catechin (1) $827.6 \mathrm{mg}$ and its dimer procyanidin B3 (2) $219.6 \mathrm{mg}$ and $\beta$-sitosterol-D-glucoside (3) $87.4 \mathrm{mg}$.

\section{UPLC Analysis}

An aliquot $(5 \mu \mathrm{L})$ of the TSSB EtOAc fraction was injected in the UPLC. The analysis was carried out by the Waters UPLC system (Acquity UPLC XevoQTof), using a UPLC BEH C18 analytical column (1.7 $\mu \mathrm{m}$, $2.1 \times 100 \mathrm{~mm})$ according to previously reported ${ }^{5}$.

\section{A No-Choice Test for Antitermite Activity}

A no-choice test was employed for evaluating termiticidal and antifeedant activities according to the previous method with modification ${ }^{7}$. The doses of TSSB MeOH and TSS MeOH extracts in the dried filter paper was prepared to $5 \%$, and $20 \%$ (sample weight/filter paper weight $\times 100 \%$ ). The isolated compounds, diastereoisomer catechin, and galloylated catechin were prepared to $0.8 \%$. The samples were dissolved in $500 \mu \mathrm{L}$ methanol, and the resulting solution was applied to filter papers (Whatman No. 1), and the filter papers were dried overnight in a vacuum desiccator. Filter paper treated with methanol only was used as 
the control. Thirty-three active termites (30 workers and 3 soldiers) from the adult of Coptotermes curvignathus were added to Petri dishes $(90 \mathrm{~mm}$ in dia $\times 20 \mathrm{~mm}$ height). The test dishes with covers were then placed on wet cloth in a plastic tray and kept in a dark room at room temperature $\left(28^{\circ} \mathrm{C} \pm 2\right)$ and $80 \%$ $\pm 5 \mathrm{RH}$ for 8 days (extracts) and 21 days for isolated compounds. A few drops of water were periodically added to the bottom edge of each Petri dish. The number of dead termites was counted daily, and the weight loss of filter paper was calculated at the end of the test. Three replications were performed for each sample. The termicidal and antifeedant activity were evaluated from the termite mortality (\%) average, and the mass loss $(\%)$ of filter paper ${ }^{8}$.

\section{Statistical Analysis}

Duncan multiple comparison tests was used to evaluate differences in percent mortality and mass loss in antitermite activities. Results with $P<0.05$ were considered significant. Calculations were performed using statistical software (SPSS 16.0).

\section{RESULTS AND DISCUSSION}

\section{Extraction and Fractionation of Toona sinensis Stem Bark and Stem Wood by Bioassay-Guided}

The stem bark (TSSB) and stem wood (TSS) of T. sinensis were extracted at room temperature with methanol and afforded TSSB MeOH extract (207.6 g) and TSS MeOH extract (27.15 g). Initially, we evaluated the antitermite activity of $\mathrm{MeOH}$ extracts both of stem bark and stem wood of $T$. sinensis against Coptotermes curvignathus using the no-choice test. When tested initially at $5 \% \mathrm{w} / \mathrm{w}$ in no-choice feeding test, methanol extracts both of TSSB and TSS showed the Coptotermes curvignathus termite dead compared to control were $35 \%$ and $65 \%$ after 4 days, $66.67 \%$ and $96.67 \%$, after 7 days, and $100 \%$ after 8 days successively. After the dose increased to $20 \% \mathrm{w} / \mathrm{w}$, the termite dead was increased to $100 \%$ after 4 days for both of extracts (Table-1). The above data suggested that both of the extracts contained antitermitic compounds, the results similarly with reported other tropical hardwood extracts ${ }^{9-11}$. On the statistical analysis, termiticidal activity both of methanol extracts are no significantly different at a doses of 5\% w/w and 20\% w/w after 8 and 4 days successively. LC-chromatogram of an analysis of TSSB EtOAc extract (Figure-1) is similar to LC-chromatogram of stem wood EtOAc extract that reported by Kakumu et al. ${ }^{5}$. For the economical reason we further investigation of stem bark extract of $T$. sinensis.

Table-1: Antitermite activity of Toona sinensis extracts against Coptotermes curvignathus

\begin{tabular}{l|r|r|r}
\hline \multirow{2}{*}{ Extracts } & \multicolumn{3}{|c}{$\begin{array}{c}\text { Mortality of termite }(\%)^{\mathrm{a}} \\
\text { Recorded over time }\end{array}$} \\
\cline { 2 - 4 } & 4 days & 7 days & 8 days \\
\hline TSSB MeOH 5\% & $35 \mathrm{~b}$ & $66.67 \mathrm{c}$ & $100 \mathrm{~d}$ \\
\hline TSSB MeOH 20\% & $100 \mathrm{~d}$ & & \\
\hline TSS MeOH 5\% & $65 \mathrm{c}$ & $96.67 \mathrm{~d}$ & $100 \mathrm{~d}$ \\
\hline TSS MeOH 20\% & $100 \mathrm{~d}$ & & \\
\hline Control $(\mathrm{MeOH})$ & $0 \mathrm{a}$ & $0 \mathrm{a}$ & $0 \mathrm{a}$ \\
\hline
\end{tabular}

${ }^{a}$ Numbers followed by different letters (a-d) on mortality (\%) are significantly different at the level of $P<0.05$ according to Duncan multiple comparison test.

\section{Isolation of Ethyl Acetate Fraction of Toona sinensis Stem Bark by Bioassay-Guided}

To identify the potential compounds responsible for antitermite activity, in this study we focus to polar compounds of Toona sinensis stem bark. The EtOAc fraction of stem bark of T. sinensis (TSSB EtOAc) was separated by column chromatography (CC) using silica gel. (+)-Catechin (1) and its dimer procyanidin B3 (2) and $\beta$-sitosterol-D-glucoside (3) were isolated (Scheme-1). The structure of this compound was confirmed by ${ }^{1} \mathrm{H}$ and ${ }^{13} \mathrm{C}-\mathrm{NMR}$; DEPT, COSY, HMBC, HMQC, and by comparing the data with the literature, in addition thin layer chromatographic behavior of the isolated $(+)$-catechin was in good agreement with the authentic (+)-catechin ${ }^{5,12-17}$. 
RASĀYAN $J$. Chem.

Vol. 10 | No. 1 |153-159 | January - March | 2017

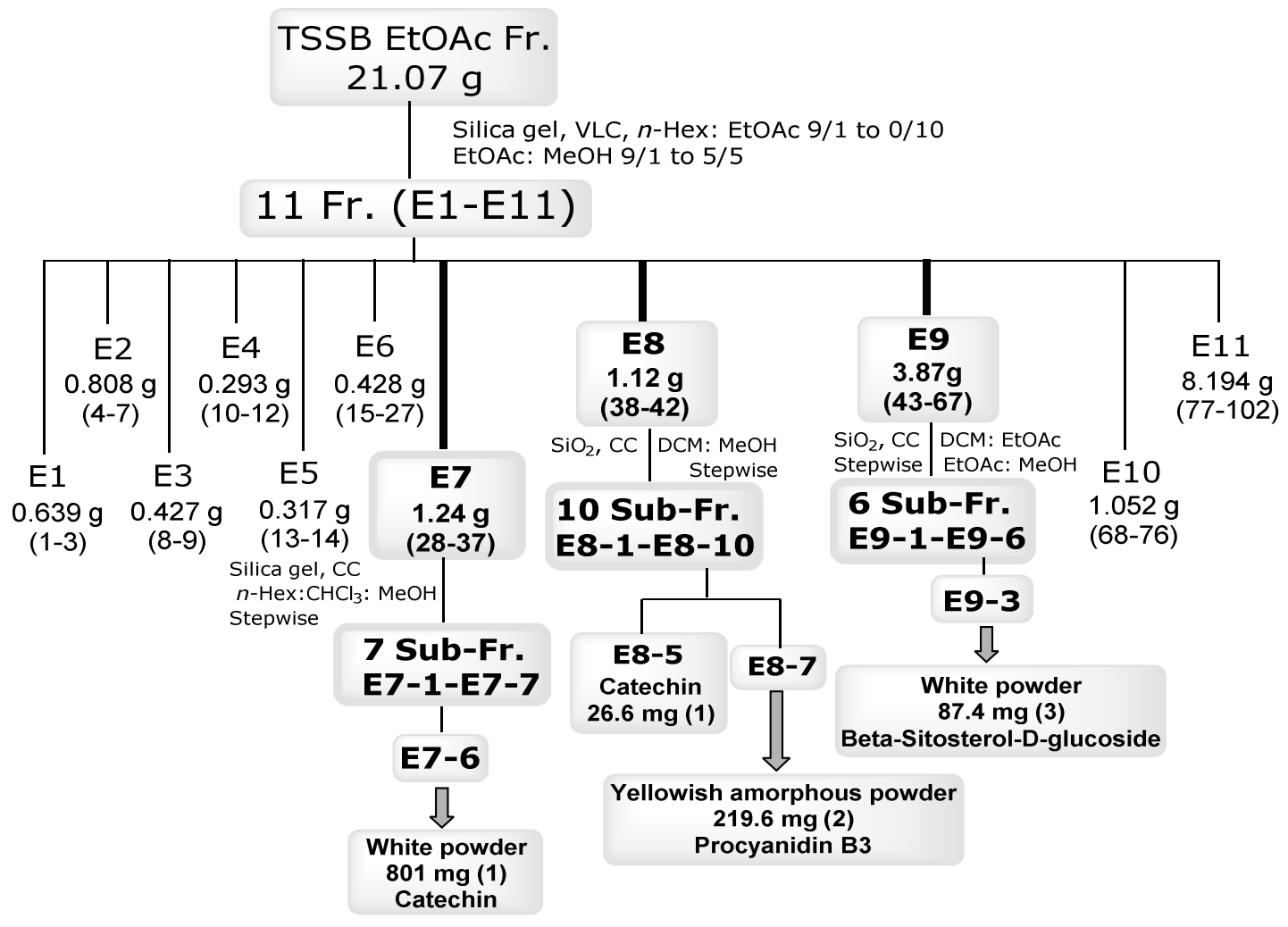

Scheme-1: Isolation scheme of TSSB EtOAc Fraction.

Compound 1 was isolated as a white powder. ${ }^{1} \mathrm{H}-\mathrm{NMR}\left(400 \mathrm{MHz} ; \mathrm{CD}_{3} \mathrm{OD}\right): \delta 6.84(1 \mathrm{H}, \mathrm{d}, J=1.8 \mathrm{~Hz}, \mathrm{H}-$ $\left.2^{\prime}\right), 6.76\left(1 \mathrm{H}, \mathrm{d}, J=7.8 \mathrm{~Hz}, \mathrm{H}-5^{\prime}\right), 6.71(1 \mathrm{H}, \mathrm{dd}, J=8.3,1.8 \mathrm{~Hz}, \mathrm{H}-6$ '), $5.93(1 \mathrm{H}, \mathrm{d}, J=2.3 \mathrm{~Hz}, \mathrm{H}-8), 5.86$ $(1 \mathrm{H}, \mathrm{d}, J=2.3 \mathrm{~Hz}, \mathrm{H}-6), 4.57(1 \mathrm{H}, \mathrm{d}, J=7.8 \mathrm{~Hz}, \mathrm{H}-2), 3.95-4.00(1 \mathrm{H}, \mathrm{m}, \mathrm{H}-3), 2.85(1 \mathrm{H}, \mathrm{dd}, J=16.3,5.5$ $\mathrm{Hz}, \mathrm{H}-4 \beta), 2.51(1 \mathrm{H}, \mathrm{dd}, J=16.3,8.3 \mathrm{~Hz}, \mathrm{H}-4 \alpha) .{ }^{13} \mathrm{C}-\mathrm{NMR}\left(100 \mathrm{MHz} ; \mathrm{CD}_{3} \mathrm{OD}\right): \delta 157.7$ (C-7), 157.5 (C5), 156.8 (C-9), 146.2 (C-3' and C-4'), 132.1 (C-1'). 120.0 (C-6'), 116.0 (C-5'), 115.2 (C-2'), 100.7 (C-10), 96.2 (C-6), 95.4 (C-8), 82.8 (C-2), 68.7 (C-3), 28.5 (C-4).

Compund 2 was isolated as yellowish amorphous powder. ${ }^{1} \mathrm{H}$ NMR $\left(400 \mathrm{MHz}, \mathrm{CD}_{3} \mathrm{OD}\right): \delta 6.83(1 \mathrm{H}, \mathrm{d}, J$ $=8.2 \mathrm{~Hz}, \mathrm{H}-\mathrm{B} 5), 6.75(1 \mathrm{H}, \mathrm{d}, J=1.8 \mathrm{~Hz}, \mathrm{H}-\mathrm{B} 2), 6.59(1 \mathrm{H}, \mathrm{d}, J=1.8 \mathrm{~Hz}, \mathrm{H}-\mathrm{E} 2), 6.68(1 \mathrm{H}, \mathrm{d}, J=8.2 \mathrm{~Hz}$, H-E5), $6.47(1 \mathrm{H}, \mathrm{dd}, J=8.2$ and $1.8 \mathrm{~Hz}, \mathrm{H}-\mathrm{B} 6), 6.25(1 \mathrm{H}, \mathrm{dd}, J=8.2$ and $1.8 \mathrm{~Hz}, \mathrm{H}-\mathrm{E} 6), 6.07(1 \mathrm{H}, \mathrm{s}, \mathrm{H}-$ D6), $5.90(1 \mathrm{H}, \mathrm{d}, J=2.2 \mathrm{~Hz}, \mathrm{H}-\mathrm{A} 8), 5.79(1 \mathrm{H}, \mathrm{d}, J=2.2 \mathrm{~Hz}, \mathrm{H}-\mathrm{A} 6), 4.76(1 \mathrm{H}, \mathrm{d}, J=7.3 \mathrm{~Hz}, \mathrm{H}-\mathrm{C} 2), 4.41$ $(1 \mathrm{H}, \mathrm{d}, J=8.3 \mathrm{~Hz}, \mathrm{H}-\mathrm{F} 2), 4.36(1 \mathrm{H}, \mathrm{dd}, J=9.2$ and $7.8 \mathrm{~Hz}, \mathrm{H}-\mathrm{C} 3), 4.27(1 \mathrm{H}, \mathrm{d}, J=9.2 \mathrm{~Hz}, \mathrm{H}-\mathrm{C} 4), 3.81$ $(1 \mathrm{H}, \mathrm{dt}, J=7.8$ and $4.4 \mathrm{~Hz}, \mathrm{H}-\mathrm{F} 3), 2.76(1 \mathrm{H}, \mathrm{dd}, J=16.3$ and $5.4 \mathrm{~Hz}, \mathrm{H}-\mathrm{F} 4 \beta), 2.49(1 \mathrm{H}, \mathrm{dd}, J=16.3$ and $7.8 \mathrm{~Hz}, \mathrm{H}-\mathrm{F} 4 \alpha) .{ }^{13} \mathrm{C}$ NMR $\left(100 \mathrm{MHz}, \mathrm{CD}_{3} \mathrm{OD}\right): \delta 158.5,157.1,157.0,155.7,155.6,154.9,146.2,145.9$, $145.7,145.5,132.5,132.0,120.9,120.1,116.3,116.1,116.0,115.4,108.1,107.1,102.1,97.4,97.2,96.7$, $96.1,83.8,82,7,73.5,68.8,38.4,28.6$.

Antitermite Activity of Isolated Compounds, Catechin Diastereoisomer, and Galloylated Catechin We evaluated the antitermite activities of isolated compounds (+)-catechin (1), procyanidin B3 (2) and $\beta$ sitosterol-D-glucoside (3). In addition, we tested the (-)-epicatechin, (-)-epicatechin gallate and (-)epigallocatechin gallate together with isolated compounds to compare their antitermite activity with (+)catechin and catechin dimer. The results of which are summarized in Table-2. The results showed that the average termite mortality all of the compounds tested at a dose of $0.8 \% \mathrm{w} / \mathrm{w}$ less than $50 \%$ by day 7 except control and $\beta$-sitosterol-D-glucoside. After 14 days feeding exposure with (+)-catechin and its related 
RASĀYAN J. Chem.

Vol. 10 | No. 1 |153-159 | January - March | 2017

compounds, (+)-catechin showed $50.51 \%$ termite mortality on average and significantly higher than control and $\beta$-sitosterol-D-glucoside but no significant difference than (-)-epicatechin (39.39\%) and (-)epigallocatechin gallate $(43.43 \%)$ on statistical analysis. The termite mortality all of the compounds increased slightly after 21 days, while (+)-catechin (59.60\%) showed mortality higher than other compounds, but no significant different than its dimer procyanidin B3, diastereoisomer (-)-epicatechin) and (-)-epigallocatechin gallate. The termites least consumed the filter paper treated with (+)-catechin with the mass loss of the filter paper (avg. 7.24\%) being significantly different from the control (avg. 19.79\%) and other compounds in laboratory bioassay, while $\beta$-sitosterol-D-glucoside showed termite feeding preference. The result was agreement with previously reported that catechin had good termite feeding deterrence and toxicity at treatment levels of $4 \%$ and $6 \%$ tested $^{18}$. Ohmura et al. (2000) suggest that some flavonoids useful as termite control agents because they are abundant in plants ${ }^{19}$, and among plant phenolics, flavonoids are known good antifeedant agent ${ }^{20}$.

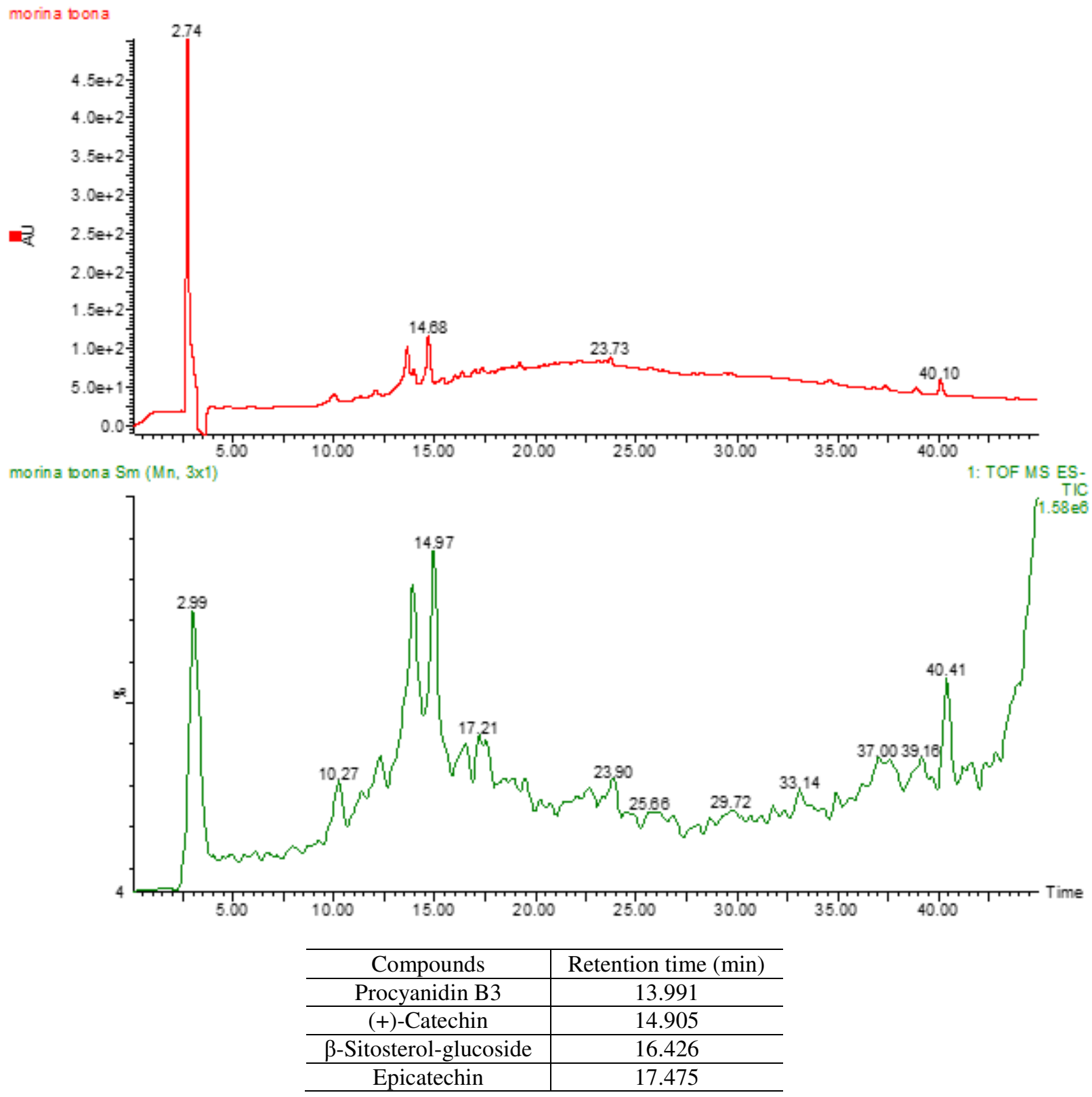

Fig.-1: LC-Chromatogram of ethyl acetate fraction of Toona sinensis stem bark 
<smiles>Oc1cc(O)c2c(c1)O[C@H](c1ccc(O)c(O)c1)[C@H](O)C2</smiles>

$(+)$-Catechin (1)<smiles>Oc1cc(O)c2c(c1)O[C@H](c1ccc(O)c(O)c1)[C@H](O)C2</smiles>

(-)-Epicatechin (4)<smiles>Oc1cc(O)c2c(c1)O[C@H](c1ccc(O)c(O)c1)[C@H](O)[C@H]2c1c(O)cc(O)c2c1O[C@H](c1ccc(O)c(O)c1)[C@H](O)C2</smiles>

Procyanidin B3 (2)<smiles>O=C(O[C@H]1Cc2c(O)cc(O)cc2O[C@@H]1c1ccc(O)c(O)c1)c1cc(O)c(O)c(O)c1</smiles>

(-)-Epicatechin gallate (5)<smiles>CC[C@H](CC[C@H](C)[C@H]1CCC2[C@@H]3CC=C4C[C@@H](O[C@@H]5O[C@H](CO)[C@@H](O)[C@H](O)[C@H]5O)CC[C@]4(C)[C@H]3CC[C@]21C)C(C)C</smiles>

Beta-Sitosterol-D-Glucoside (3)<smiles>O=C(O[C@H]1Cc2c(O)cc(O)cc2O[C@H]1c1cc(O)c(O)c(O)c1)c1cc(O)c(O)c(O)c1</smiles>

(-)-Epigallocatechin gallate (6)

Fig.-2: Chemical structures of isolated compounds, diastereoisomer catechin, and galloylated catechin.

Table-2: Antitermite activities of isolated compounds, catechin diastereoisomer, and galloylated catechin against Coptotermes curvignathus

\begin{tabular}{c|c|c|c|c}
\hline \multirow{2}{*}{ Compounds } & \multicolumn{3}{|c|}{$\begin{array}{c}\text { Mortality of termite }(\%)^{\mathrm{a}} \\
\text { recorded over time }\end{array}$} & $\begin{array}{c}\text { Mass Loss (\%) } \\
\text { filter paper }\end{array}$ \\
\cline { 2 - 5 } & $7 \mathrm{days}$ & $14 \mathrm{days}$ & $21 \mathrm{days}$ & 21 days \\
\hline Control (MeOH) & $0 \mathrm{a}$ & $0 \mathrm{a}$ & $3.03 \mathrm{a}, \mathrm{b}$ & $19.79 \mathrm{D}$ \\
\hline$\beta$-Sitosterol-D-glucoside & $0 \mathrm{a}$ & $0 \mathrm{a}$ & $3.03 \mathrm{a}, \mathrm{b}$ & $20.98 \mathrm{D}$ \\
\hline$(+)-C a t e c h i n$ & $46.46 \mathrm{~d}, \mathrm{e}$ & $50.51 \mathrm{e}$ & $59.60 \mathrm{e}$ & $7.24 \mathrm{~A}$ \\
\hline Procyanidin B3 & $28.28 \mathrm{~b}, \mathrm{c}, \mathrm{d}$ & $30.30 \mathrm{~b}, \mathrm{c}, \mathrm{d}$ & $36.36 \mathrm{c}, \mathrm{d}, \mathrm{e}$ & $12.73 \mathrm{C}$ \\
\hline (-)-Epicatechin & $30.30 \mathrm{~b}, \mathrm{c}, \mathrm{d}$ & $39.39 \mathrm{c}, \mathrm{d}, \mathrm{e}$ & $44.44 \mathrm{~d}, \mathrm{e}$ & $8.04 \mathrm{~A}, \mathrm{~B}$ \\
\hline (-)-Epicatechin gallate & $16.16 \mathrm{a}, \mathrm{b}$ & $24.24 \mathrm{~b}, \mathrm{c}$ & $30.30 \mathrm{~b}, \mathrm{c}, \mathrm{d}$ & $10.21 \mathrm{~B}$ \\
\hline (-)-Epigallocatechin gallate & $37.37 \mathrm{c}, \mathrm{d}, \mathrm{e}$ & $43.43 \mathrm{c}, \mathrm{d}, \mathrm{e}$ & $44.44 \mathrm{~d}, \mathrm{e}$ & $8.15 \mathrm{~A}, \mathrm{~B}$ \\
\hline
\end{tabular}

${ }^{a}$ Numbers followed by different letters (a-e) on mortality (\%) are significantly different at the level of $P<0.05$ according to Duncan multiple comparison tests.

${ }^{b}$ Numbers followed by different letters (A-D) on mass loss (\%) are significantly different at the level of $P<0.05$ according to Duncan multiple comparison tests.

\section{CONCLUSION}

In conclusion, the result suggested that both of $\mathrm{MeOH}$ stem bark and stem wood Toona sinensis extracts contained antitermitic compounds. For the economical reason we further investigation of stem bark extract of $T$. sinensis. We have isolated two flavonoid compounds (+)-catechin (1) and its dimer procyanidin B3 (2) and one steroid compound $\beta$-sitosterol-D-glucoside (3) by bioassay guided.

In addition, we tested the (-)-epicatechin, (-)-epicatechin gallate and (-)-epigallocatechin gallate together 
with isolated compounds. The results showed that (+)-catechin had the highest antifeedant and termiticidal activity after 21 days exposure to all other compounds tested at a low dose $(0.8 \% \mathrm{w} / \mathrm{w})$, but no significant difference in mortality to its dimer procyanidin B3, diastereoisomer (-)-epicatechin and galloylated catechin (-)-epigallocatechin gallate on statistical analysis. Future investigations will be focused on antitermite activity of non-polar extract or essential oil of Toona sinensis stem bark with choice and no-choice tests that will be possible to identify the compounds which more antifeedant, and termiticidal properties.

\section{ACKNOWLEDGMENT}

The authors would like to acknowledge the financial support of the Ministry of Research, Technology and Directorate General of Higher Education, The Republic of Indonesia for a research grant International research collaboration and scientific publication (054/SP2H/PL/DIT-LITABMAS/11/2015).

\section{REFERENCES}

1. J.M. Edmonds, and M. Staniforth, Curtis's Botanical Magazine, 15, 186 (1998).

2. S. Parvin, X.N. Zeng, and T. Islam, Revista Brasileira de Entomologia, 56(3), 354 (2012).

3. W. Kraus, W. Grimminger, and G. Sawitzki, Angewandte Chemie International Edition in English, 17(6), 452 (1978).

4. Y.C. Chia, R. Rajbanshi, C. Calhoun, and R.H. Chiu, Molecules, 15(11), 8377 (2010).

5. Kakumu, M. Ninomiya, M. Efdi, M. Adfa, M. Hayashi, K. Tanaka, and M. Koketsu, Bioorganic \& Medicinal Chemistry Letters, 24(17), 4286 (2014).

6. CHEN Lin, Journal of Anhui Agricultural Sciences, 27, 078 (2010).

7. S.T. Chang, and S.S. Cheng, Journal of Agricultural and Food Chemistry, 50(6), 1389 (2002).

8. M. Adfa, Y. Hattori, T. Yoshimura, and M. Koketsu, International Biodeterioration \& Biodegradation, 74, 129 (2012).

9. A.L. Santana, C.A., Maranhão, J.C. Santos, F.M. Cunha, G.M. Conceição, L.W. Bieber, and M.S. Nascimento, International Biodeterioration \& Biodegradation, 64(1), 7 (2010).

10. F.L. Carter, and C.R. de Camargo, Wood and Fiber Science, 15(4), 350 (2007).

11. F.L. Carter, R.H. Beal, and J.D. Bult-Man, Wood Science, 8(1), 406 (1975).

12. A.L. Davis, Y. Cai, A.P. Davies, and J.R. Lewis, Magnetic Resonance in Chemistry, 34(11), 887 (1996).

13. Ø.M. Andersen, and K.R Markham, Flavonoids: chemistry, biochemistry and applications. CRC press (2005).

14. Saito, N. Nakajima, A. Tanaka, and M. Ubukata, Tetrahedron, 58(39), 7829 (2002).

15. C.J. Hayes, B.P. Whittaker, S.A. Watson, and A.M. Grabowska, Journal of Organic Chemistry, 71(26), 9701 (2006).

16. M. Arora, and A.N. Kalia, International Journal of Pharmacy and Pharmaceutical Sciences, 5(1), 245 (2013).

17. M. Khatun, M. Billah, and M.A. Quader, Dhaka University Journal of Science, 60(1), 5 (2012).

18. N.S. Little, T.P. Schultz, and D.D. Nicholas, Holzforschung, 64(3), 395 (2010).

19. W. Ohmura, S. Doi, M. Aoyama, and S. Ohara, Journal of Wood Science, 46(2), 149 (2000).

20. M.S.J. Simmonds, Phytochemistry, 56(3), 245 (2001).

[RJC-1590/2017] 